\title{
Foreign Direct Investments and Their Impacts to Environment, Albania Case
}

\author{
Dr. Godiva Rembeci
}

POLIS University, International School of Architecture and Urban Development Policies

\begin{abstract}
FDI is considered as positive factor on economic growth for the hosting country, because of its contribution to the employment growth, productivity, income, transfer of know-how, export promotion of its products in international market, etc. Especially in transition economies FDI compare to other the external flows is an important source for financing the current account deficit and in addition those flows are preferable because do not create debts for the hosting country. So far, the economic impacts of FDls are almost well measured, but their impacts in other aspects such as environmental or social ones, are less recognizable and measured. By this paper the author aim to measure the share of foreign direct investments in pollution intense industries and their impacts to Albanian environment. The subject of the analysis is the FDI stock by economic activities focusing mostly to those activities determined by OECD as pollution-intensive industries, for the period 2007-2014. Both EUROSTAT and national statistical data produced by Bank of Albania are used to calculate the share of foreign investors' involvement in pollution-intensive activities. The results show that in Albania, the FDI stock in pollution intense activities has an considerable position on the total FDI stock and its level of participation is higher compare to the EU figures
\end{abstract}

Keywords: FDI stock, environment, pollution intensive industries, EUROSTAT, Bank of Albania

\section{Introduction}

FDI is regarded as positive factor on economic growth for the hosting country, because of its contribution on increasing of employment, productivity, income, transfer of know-how, export promotion of its products in international market, etc. Especially in transition economies FDI compare to other the external flows is an important source for financing the current account deficit and in addition those flows are preferable because do not create debts for the hosting country. So far, the economic impacts of FDls are almost well measured, but their impacts in other aspects such as environmental aspects, are less recognizable and measured. The official statements on the environmental impacts of FDI are characterized by three main arguments (OECD, 1998):

Countries will set its regulations based on domestic preferences and resources, those with low income should set standards low an attract pollution intensive and resource seeking FDI.

FDI increases the demand for environment quality if host-country demand for environmental quality increases as incomes rise then eventually environmental damage will began to fall (the environmental Kuznets curve argument).As FDI increases incomes it will contribute to this increased environmental demand.

FDI is cleaner than domestic investment FDI involves new technologies that are cleaner than those of domestic producers therefore encouraging FDI can improve the environmental performance of a country.

So the sustainability of FDI in the long term in the hosting countries is a matter of their impacts in the environment, because FDI may either upgrade or destroy the environment. The final result depends on a balance of macro and micro factors (UNCTAD 1999, pp. 289-312). From the macro prospective, the impact of FDI in the environment is depended very much by the type of economic activities where FDI is contributing in a given country while at the micro level depends from the level of technology used by foreign investors.

Through this paper we would like to show empirical evidence of FDI stock in pollution activities and its impact on the Albanian environment. In determining the polluting industries, OECD/EUROSTAT classification will be used and statistical data published both by EUROSTAT and Bank of Albania are also going to be used, to estimate the share of foreign investors' involvement in pollution-intensive activities in Albania. 


\section{FDI in Pollution-Intensive activities in Albania}

The analysis covers the Albanian FDI stock by economic branches and its impact to environment, for the period 2007-2014, with the main focus to FDI stocks located in pollution-intensive industries and services. The industries perceived as potentially highly polluting are: mining and quarrying, wood, publishing and printing, refined petroleum \& other treatments, chemical products, rubber and plastic products and metal products. In addition some services activities are also perceived as more burdensome for the environment such as: hotels, restaurants and transport.(OECD,Eurostat,1999)

Data published by Bank of Albania are used for calculations of the share and rate of inward FDI stock located in the pollutionintensive manufacturing industries and services. As EU reference standards are used the data published by Report London Economics 2009, p.56 (based on EUROSTAT data) related to the average rate of intense pollution activities to total FDI stock for the EU27.

FDI stock in Albania is facing a positive growth rate during the period 2007-2014 and current stock is estimated to be about 4.5 billion of euro or is more than doubled compared to 2007 year. The yearly average long term growth rate is evaluated for about $13 \%$, while the highest growth rate is achieved in year 2011 , for about $40 \%$.

The economic sector with the highest contribution in the total FDI stock for about 27\% (reference year 2014) is the sector " I", (as a sum of transport and communication activities) , but nevertheless communication branch represent in average $95 \%$ of the "l" sector during the recent three years. Last year the communication branch is increased for about 57 percent compare with the previous one and it's almost doubled compared with 2007 year.

The growth rate of the "communication" sector is followed by the" financial intermediation" sector, with its contribution for about $17 \%$ of the total FDI stock. This sector has recognized a positive growth during the period 2007-2013 although the financial crises around the world, but in 2014 the FDI stock in financial intermediation has faced a negative growth rate for about 6 percent.

In the third position is placed the "mining and quarrying" sector for about $15 \%$ of the total stock. Within the sector, extracting of petroleum is the major activity who contributes for about 90 percent to the FDI stock of this sector. As for the rest of other activities, among important activities should be mentioned "Electricity, gas and water supply" branch with the contribution about 9 percent of the total FDI stock. This branch has been developed quite a lot in the recent years due to a lot of concession contracts in hydropower energy. Only the last year the branch has faced an increased for about 12 times more, compare to the previous year. Another important sector is manufacturing sector with an equal contribution as electricity sector for about 9 percent to the total FDI stock. Within this sector, the branch of " manufacture of other non-metallic mineral products" represent about 55 percent of the total FDI of this sector and the rest of the stock is mostly distributed among food, textile and leather production branches.

As per services sector, it's interesting to notice then "business activity" sector is facing quite an increase during the recent years and this is due to new activity introduced in Albania named "call-center". In the current year 2014, the FDI stock of this activity is increased 5 times compare to the previous year.

Detailed analyses research (ref. statistical tables in annex1) shows that:

Total FDI stock in pollution activities (both in industry and service sectors) in case of Albania, represent in long term yearly average, about 18 percent of the total FDI stocks. The rate of participation of FDI stock in pollution activities, during the period, is increased from 11 percent in the year 2007 to 18 percent in the last year of the period. The highest level of the rate of participation is achieved in the year 2012 for about 24 percent of the total FDI stocks.

The majority of the FDI stock in pollution activities is due to FDI stocks in industries for about 70 percent in long term yearly average and the rest of the stock is represented by the FDI stock in service pollution activities.

Economic sectors, during the period 2007-20014, have performed different trends of developments, so activities of pollution industries show a very high positive growth rate and the FDI stocks is almost quadrupled, while the services sector show a negative growth rate in average $(-3 \%)$ and the stock is reduced at about 25 percent in 2014, compared with the stock at the beginning of period.

Total FDI stock in pollution intensive industries, during the period 2007-2014, has shown an increased of the growth rate, estimated to be in long-term yearly average for about 14 percent, while in the last year this stock is representing about 16 
percent of the total FDI stock in the country. The highest level of this stock is estimated to be in the year 2012, for about 22 percent of the total FDI stock.

The shares of inward FDI stock located in pollution intensive industries in the total FDI stock in Albania is higher than the average for the EU27 (see table 5). As noticed in the first paragraph, the average rate for Albania is about 14 percent while in the EU, this stock represent about 9 percent. The situation for the Albania is worsening during the recent years because the rate of participation for those so called dirty-industries to the total FDI stocks has reached about 20 percent especially for the period 2011-2014.

Albania has no large foreign direct investment stock in" mining and quarrying in metal ores" industries and the long -term yearly average of the growth rate of this sector is about $2 \%$ and the estimation is based on the contribution of the sector over the total FDI stock in the country. Meanwhile if we analyze the importance of this branch within total FDI stock in pollution intensive industries, the situation is different and the rate of contribution is increased in average to 12 percent. Nevertheless is important to notice that the absolute value of the FDI stock in mining and quarrying sector is increased during the period, although the rate of importance to the total FDI stock is decreased (see Tables 2-3).

The total of FDI stock for the "mining and quarrying "sector, compared with the level of participation of this sector to EU results, shows that in case of Albania the growth rate is lower although the trend so far is facing a positive growth.

The sector of "Extraction of crude petroleum and natural gas" has been increased during the 2007-2014 with average yearly growth rate for about 10 percent. The position of this sector in the beginning of the period (2007-2014) was really unimportant, but during the years the growth rate has faced a significance increase, achieving the highest level in year 2012 for about 19 percent of the total FDI stock in the country.

The presence of this sector is very much evident during the recent years also as a primary sector contributing to the total FDI stock for about 21percent. Analyses of the contribution of this branch within the total FDI stock of pollutions intensive industries show that the growth rate of the sector has been increased enormously during the period 2009-2013 estimated as a yearly average for about 90 percent and further more the rate of participation has been increased from 1 percent in 2007 year to 82 percent in 2014 . The positive growth rate of this branch is dedicated to the privatization of the public company in extraction of petroleum by the foreign investors as well as to other concession contracts in exploitation of the petroleum. The share of this sector to total FDI stock in pollution industries, compare with EU figures, shows a very high presence in case of Albania for about 13 percent ( ref. year 2014) meanwhile in EU, the presence of this sector is insignificant, almost zero percent.

Metal product is another sector with a positive growth rate for the period 2007-2011, estimated as long term yearly average for about 2 percent, but after that period the FDI stock of this branch has been almost halved, facing a fluctuating growth rate less than 0.5 percent. Comparing the rate of share of this sector with the EU figures, it comes out that in case of Albania the level of participation of this sector is lower especially during the recent years.

Regarding the rest of pollution intensive industries, their contribution to the total FDI stock, according to the analyses, shows that these activities accounts all together less than 1.5 percent of the total of FDI stock. Among them, only the branch of "wood and publishing" shows a positive growth of the stock from 1 million of euro in 2007, to 16 million euro in 2014, meanwhile the other activities are facing a tendency toward reduction of the stock.

As per FDI stock in services sector in case of Albania, the first thing to notice is the proportion of this stock to the total FDI stock in the country. According to the analyses this stock represent more than 50 percent of the total FDI stock and the second fact to be mentioned is the positive growth rate of this stock estimated in long term yearly average for about 9.3 percent and in the year 2014 the stock has been almost doublet compared with 2007 year.

Within service sectors FDI stock, the FDI stocks in pollution intense services sectors represent an average about 4 percent of the total FDI service sector. The highest level is measured in 2007 for about 7 percent and the lowest level in 2014 for about $2 \%$.

The majority part of service sector in pollution activities is represented by the FDI stocks in the hotels and restaurants activities, for about 65 percent of the total. Although the growth rate of the both activities shows a negative growth rate, it's interesting to underline that the reduction is a tendency for the hotels and restaurants activity meanwhile the transport activity shows smooth fluctuating of the growth rate. 


\section{Current situation of national environment policies towards EU standards}

Albania is a candidate country since June 2014 and is smoothly implementing its obligation according to SAA and specifically regarding the environmental area. Although approximation with EU legislation has been advanced, still further efforts are needed in order to complete and adopt the EU legislation and regulations in this area, within 2020 year, as planned by the Albanian government (EC Brussels,2015). More specifically in the area of industrial pollution control and risk management, the following EU directives are recently partially adopted:

2010/75/EU related with prevention and integrated control of industrial pollution

2001/80/EU related with the limitation of emissions of certain pollutants into the air from large combustion plants

EU regulation related to the establishment of the register of emissions and transfer of pollutants

Meanwhile the law transposing the EU Directive on the control of major accident hazards has still not been adopted. Preventive measures are not enforced and risk preparedness is not applied. Self-monitoring of emissions is not reliable. In October, a task force was set up to inspect and evaluate the environmental compliance of oil exploration companies. A framework law on chemicals management has not been adopted yet. A decision regulating import of ozone depleting gases (HFCF) over the coming years until 2040 was amended in line with Albania's commitments under the Montreal Protocol.(MoE, annual report, 2015)

As a conclusion, transition period is very much needed in order to fulfill the EU requirements in this area as well as the financial support.

Challenges for the future:

Improve the current environmental legislation towards EU standards.

Strengthening the implementations of environmental law requirements.

Consolidation of the national monitoring system according to EU standards.

Improve cooperation and coordination efforts of central and local government, with regards to the protection of environment. Better management system to identify and motivate the use of modern technology in industrial and transport sectors.

Invest in public education to increase the awareness toward protection of environment

\section{Conclusions:}

The current structure of FDI stock by economic activities, more specifically the share of polluting activities to the total FDI stock, clearly shows that from environmental point of view, Albania is far from EU standards and further more the pollutions intense activities demonstrate a positive growth rate to the total FDI stock from $11 \%$ in 2007 to $18 \%$ in 2014, meanwhile in EU, the growth rate is decreased from $9.3 \%$ to $8 \%$ for the same period.

So far the majority of FDI stock in pollution-intense industries is located to extraction industry related mostly to the exploitation of petroleum and its share to the total stock of FDI in polluting activities in industry is estimated for more than 80 percent in the recent years.

As per the polluting activities in service sector, although the services sector represent the majority part of the total FDI stock of the country, its share to the total FDI stock is reduced during the study period and currently accounts only for about 2 percent.

Shifting from current technologies to the modern one, especially for those activities "contributing" in the environment pollution, might contribute in the reduction of the negative impact of the polluting activities to environment.

Potential reduction of the share of FDI stock in polluting industries in the total inward FDI stock might be achieved also by remodeling the economic development model of the country towards activities less polluting.

Due to the lack of detailed FDI stock data by economic activity, the results should be read carefully, because either some activities (classified as pollution intense industries) might be excluded or some other might be overloaded. 
Further analyses should be undertaken combining both more detailed FDI stock data and environmental statistics to get a complete picture on the impacts that foreign direct investments in pollution activities have on the environment.

\section{Annex 1: Statistical tables}

Table 1.FDI stock by economic activities in Albania, for 2007-2014, in million of euro

\begin{tabular}{|l|l|l|l|l|l|l|l|l|l|}
\hline $\begin{array}{l}\text { COD } \\
\text { E }\end{array}$ & ECONOMIC ACTIVITY & 2007 & 2008 & 2009 & 2010 & 2011 & 2012 & 2013 & 2014 \\
\hline A & $\begin{array}{l}\text { Agriculture, hunting and } \\
\text { forestry }\end{array}$ & 6 & 19 & 6 & 7 & 4 & 1 & 1 & 1 \\
\hline B & Fishing & - & 2 & 3 & 2 & 4 & - & - & - \\
\hline C & Mining and quarrying & 10 & 29 & 147 & 311 & 612 & 810 & 742 & 677 \\
\hline D & Manufacturing & 218 & 363 & 352 & 378 & 431 & 335 & 394 & 412 \\
\hline E & $\begin{array}{l}\text { Electricity, gas and water } \\
\text { supply }\end{array}$ & 10 & 18 & 95 & 118 & 247 & 30 & -4 & 399 \\
\hline F & Construction & 132 & 196 & 189 & $(1)$ & 11 & 142 & 140 & 107 \\
\hline G & $\begin{array}{l}\text { Wholesale and retail trade; } \\
\text { repair of motor vehicles, } \\
\text { motorcycles and personal } \\
\text { and household goods }\end{array}$ & 99 & 271 & 253 & 240 & 217 & 157 & 156 & 189 \\
\hline H & Hotels and restaurants & 94 & & & & & & & \\
\hline I & $\begin{array}{l}\text { Transport, storage and } \\
\text { communication }\end{array}$ & 590 & 383 & 357 & 400 & 389 & 789 & 1,157 & 1,219 \\
\hline J & Financial intermediation & 588 & 548 & 614 & 700 & 715 & 753 & 818 & 768 \\
\hline K & $\begin{array}{l}\text { Real estate, renting and } \\
\text { business activities }\end{array}$ & 57 & 25 & 42 & 63 & 83 & 90 & 361 & 400 \\
\hline M & Education & 2 & 3 & 3 & 4 & 6 & 7 & 13 & 17 \\
\hline N & Health and social work & - & 26 & 48 & 64 & 47 & 36 & 33 & 29 \\
\hline O & $\begin{array}{l}\text { Other community, social and } \\
\text { personal service activities }\end{array}$ & 13 & 8 & 9 & 12 & 9 & 18 & 19 & 26 \\
\hline Q & $\begin{array}{l}\text { Extra-territorial organizations } \\
\text { and bodies }\end{array}$ & - & - & 10 & 24 & 36 & - & - & - \\
\hline & Other manufacture & 10 & 76 & 56 & 38 & 521 & 616 & 160 & 189 \\
\hline & Total FDI & 1,829 & 2,061 & 3 & 2,436 & 2 & & & \\
\hline
\end{tabular}

Source: Bank of Albania, IIP statistics, breakdown by activities according to NACE rev.1

Table 2.FDI stock in pollution-intensive industries in Albania, 2007-2014, in million of euro, and in \% over total FDI stock

\begin{tabular}{|c|c|c|c|c|c|c|c|c|c|c|c|c|c|c|c|c|}
\hline \multirow{2}{*}{$\begin{array}{l}\text { FDI } \\
\text { stock } \\
\text { in } \\
\text { million } \\
\text { of euro }\end{array}$} & \multicolumn{2}{|c|}{2007} & \multicolumn{2}{|c|}{2008} & \multicolumn{2}{|c|}{2009} & \multicolumn{2}{|c|}{2010} & \multicolumn{2}{|c|}{2011} & \multicolumn{2}{|c|}{2012} & \multicolumn{3}{|c|}{2013} & 2014 \\
\hline & $\begin{array}{l}\text { in } \\
\text { val } \\
\text { ue }\end{array}$ & $\begin{array}{l}\text { in } \\
\%\end{array}$ & $\begin{array}{l}\text { in } \\
\text { val } \\
\text { ue }\end{array}$ & $\begin{array}{l}\text { in } \\
\%\end{array}$ & $\begin{array}{l}\text { in } \\
\text { val } \\
\text { ue }\end{array}$ & in \% & $\begin{array}{l}\text { in } \\
\text { val } \\
\text { ue }\end{array}$ & in $\%$ & $\begin{array}{l}\text { in } \\
\text { val } \\
\text { ue }\end{array}$ & in $\%$ & $\begin{array}{l}\text { in } \\
\text { val } \\
\text { ue }\end{array}$ & $\begin{array}{l}\text { in } \\
\% \\
\end{array}$ & $\begin{array}{l}\text { in } \\
\text { val } \\
\text { ue }\end{array}$ & in $\%$ & $\begin{array}{l}\text { in } \\
\text { valu } \\
\mathrm{e}\end{array}$ & in $\%$ \\
\hline $\begin{array}{l}\text { Mining } \\
\text { and } \\
\text { quarryi } \\
\text { ng }\end{array}$ & 9 & $\begin{array}{l}0.5 \\
\% \\
\end{array}$ & 23 & $\begin{array}{l}1.1 \\
\% \\
\end{array}$ & 42 & $\begin{array}{l}1.9 \\
\%\end{array}$ & 41 & $\begin{array}{l}1.7 \\
\%\end{array}$ & 73 & $\begin{array}{l}2.1 \\
\%\end{array}$ & 83 & $2 \%$ & 76 & $\begin{array}{l}1.8 \\
\% \\
\end{array}$ & 76 & $\begin{array}{l}1.7 \\
\%\end{array}$ \\
\hline $\begin{array}{l}\text { Extract } \\
\text { ion of } \\
\text { crude } \\
\text { petrole } \\
\text { um } \\
\text { and }\end{array}$ & 1 & $\begin{array}{l}0.1 \\
\%\end{array}$ & 7 & $\begin{array}{l}0.3 \\
\%\end{array}$ & 104 & $\begin{array}{l}4.6 \\
\%\end{array}$ & 270 & $\begin{array}{l}11 . \\
1 \%\end{array}$ & 539 & $\begin{array}{l}15 . \\
9 \%\end{array}$ & 728 & $\begin{array}{l}19 \\
\%\end{array}$ & 666 & $\begin{array}{l}16 . \\
2 \%\end{array}$ & 604 & $\begin{array}{l}13 . \\
3 \%\end{array}$ \\
\hline
\end{tabular}




\begin{tabular}{|c|c|c|c|c|c|c|c|c|c|c|c|c|c|c|c|c|}
\hline $\begin{array}{l}\text { natural } \\
\text { gas; }\end{array}$ & & & & & & & & & & & & & & & & \\
\hline $\begin{array}{l}\text { Wood, } \\
\text { publish } \\
\text { ing } \\
\text { and } \\
\text { printin } \\
\mathrm{g}\end{array}$ & 1 & $\begin{array}{l}0.1 \\
\%\end{array}$ & 8 & $\begin{array}{l}0.4 \\
\%\end{array}$ & 9 & $\begin{array}{l}0.4 \\
\%\end{array}$ & 19 & $\begin{array}{l}0.8 \\
\%\end{array}$ & 22 & $\begin{array}{l}0.6 \\
\%\end{array}$ & 10 & $0 \%$ & 14 & $\begin{array}{l}0.3 \\
\%\end{array}$ & 16 & $\begin{array}{l}0.4 \\
\% \\
\end{array}$ \\
\hline $\begin{array}{l}\text { Refine } \\
d \\
\text { petrole } \\
\text { um \& } \\
\text { other } \\
\text { treatm } \\
\text { ents }\end{array}$ & 0 & $\begin{array}{l}0.0 \\
\%\end{array}$ & 0 & $\begin{array}{l}0.0 \\
\%\end{array}$ & 0 & $\begin{array}{l}0.0 \\
\%\end{array}$ & 0 & $\begin{array}{l}0.0 \\
\%\end{array}$ & 0 & $\begin{array}{l}0.0 \\
\%\end{array}$ & 0 & $0 \%$ & 0 & $\begin{array}{l}0.0 \\
\%\end{array}$ & 0 & $\begin{array}{l}0.0 \\
\%\end{array}$ \\
\hline $\begin{array}{l}\text { Chemi } \\
\text { cal } \\
\text { produc } \\
\text { ts }\end{array}$ & 1 & $\begin{array}{l}0.1 \\
\%\end{array}$ & 9 & $\begin{array}{l}0.4 \\
\% \\
\end{array}$ & 11 & $\begin{array}{l}0.5 \\
\% \\
\end{array}$ & 13 & $\begin{array}{l}0.5 \\
\% \\
\end{array}$ & 13 & $\begin{array}{l}0.4 \\
\% \\
\end{array}$ & 2 & $0 \%$ & 9 & $\begin{array}{l}0.2 \\
\% \\
\end{array}$ & 8 & $\begin{array}{l}0.2 \\
\% \\
\end{array}$ \\
\hline $\begin{array}{l}\text { Rubbe } \\
r \text { and } \\
\text { plastic } \\
\text { produc } \\
\text { ts }\end{array}$ & 33 & $\begin{array}{l}1.8 \\
\%\end{array}$ & 14 & $\begin{array}{l}0.7 \\
\%\end{array}$ & 9 & $\begin{array}{l}0.4 \\
\%\end{array}$ & 9 & $\begin{array}{l}0.4 \\
\%\end{array}$ & 4 & $\begin{array}{l}0.1 \\
\%\end{array}$ & 4 & $0 \%$ & 4 & $\begin{array}{l}0.1 \\
\%\end{array}$ & 6 & $\begin{array}{l}0.1 \\
\%\end{array}$ \\
\hline $\begin{array}{l}\text { Metal } \\
\text { produc } \\
\text { ts }\end{array}$ & 26 & $\begin{array}{l}1.4 \\
\%\end{array}$ & 62 & $\begin{array}{l}3.0 \\
\%\end{array}$ & 53 & $\begin{array}{l}2.3 \\
\%\end{array}$ & 51 & $\begin{array}{l}2.1 \\
\%\end{array}$ & 46 & $\begin{array}{l}1.4 \\
\%\end{array}$ & 17 & $0 \%$ & 21 & $\begin{array}{l}0.5 \\
\%\end{array}$ & 24 & $\begin{array}{l}0.5 \\
\%\end{array}$ \\
\hline $\begin{array}{l}\text { Total } \\
\text { FDI } \\
\text { stock } \\
\text { in } \\
\text { pollutio } \\
\text { n } \\
\text { intensi } \\
\text { ve } \\
\text { industr } \\
\text { ies }\end{array}$ & 71 & $\begin{array}{l}3.9 \\
\%\end{array}$ & 123 & $\begin{array}{l}6.0 \\
\%\end{array}$ & 228 & $\begin{array}{l}10 . \\
1 \%\end{array}$ & 403 & $\begin{array}{l}16 . \\
5 \%\end{array}$ & 697 & $\begin{array}{l}20 . \\
5 \%\end{array}$ & 844 & $\begin{array}{l}22 \\
\%\end{array}$ & 790 & $\begin{array}{l}19 . \\
2 \%\end{array}$ & 734 & $\begin{array}{l}16 . \\
1 \%\end{array}$ \\
\hline $\begin{array}{l}\text { TOTA } \\
\text { L FDI } \\
\text { STOC } \\
\text { K }\end{array}$ & $\begin{array}{l}1,8 \\
30 \\
\end{array}$ & $\begin{array}{l}10 \\
0\end{array}$ & $\begin{array}{l}2,0 \\
61 \\
\end{array}$ & $\begin{array}{l}100 \\
\%\end{array}$ & $\begin{array}{l}2,2 \\
61 \\
\end{array}$ & $\begin{array}{l}100 \\
\%\end{array}$ & $\begin{array}{l}2,4 \\
36 \\
\end{array}$ & $\begin{array}{l}100 \\
\%\end{array}$ & $\begin{array}{l}3,4 \\
00 \\
\end{array}$ & $\begin{array}{l}100 \\
\%\end{array}$ & $\begin{array}{l}3,8 \\
93\end{array}$ & $\begin{array}{l}100 \\
\%\end{array}$ & $\begin{array}{l}4,1 \\
13\end{array}$ & $\begin{array}{l}100 \\
\%\end{array}$ & $\begin{array}{l}4,55 \\
3\end{array}$ & $\begin{array}{l}100 \\
\% \\
\end{array}$ \\
\hline
\end{tabular}

Source: Bank of Albania, IIP statistics and author's calculations, breakdown by activities according to NACE rev.1

Table 3.FDI stock in pollution-intensive industries in Albania, 2007-2014, in million of euro and in \% over total FDI stock in pollution industries

\begin{tabular}{|c|c|c|c|c|c|c|c|c|c|c|c|c|c|c|c|c|}
\hline \multirow[b]{2}{*}{$\begin{array}{l}\text { FDI stock in } \\
\text { million of euro }\end{array}$} & \multicolumn{2}{|c|}{2007} & \multicolumn{2}{|c|}{2008} & \multicolumn{2}{|c|}{2009} & \multicolumn{2}{|c|}{2010} & \multicolumn{2}{|c|}{2011} & \multicolumn{2}{|c|}{2012} & \multicolumn{2}{|c|}{2013} & \multicolumn{2}{|c|}{2014} \\
\hline & $\begin{array}{l}\text { in } \\
\text { val } \\
\text { ue }\end{array}$ & $\begin{array}{l}\text { in } \\
\%\end{array}$ & $\begin{array}{l}\text { in } \\
\text { val } \\
\text { ue }\end{array}$ & $\begin{array}{l}\text { in } \\
\%\end{array}$ & $\begin{array}{l}\text { in } \\
\text { val } \\
\text { ue }\end{array}$ & $\begin{array}{l}\text { in } \\
\%\end{array}$ & $\begin{array}{l}\text { in } \\
\text { val } \\
\text { ue }\end{array}$ & $\begin{array}{l}\text { in } \\
\%\end{array}$ & $\begin{array}{l}\text { in } \\
\text { val } \\
\text { ue }\end{array}$ & $\begin{array}{l}\text { in } \\
\%\end{array}$ & $\begin{array}{l}\text { in } \\
\text { val } \\
\text { ue }\end{array}$ & $\begin{array}{l}\text { in } \\
\%\end{array}$ & $\begin{array}{l}\text { in } \\
\text { val } \\
\text { ue }\end{array}$ & $\begin{array}{l}\text { in } \\
\%\end{array}$ & $\begin{array}{l}\text { in } \\
\text { val } \\
\text { ue }\end{array}$ & $\begin{array}{l}\text { in } \\
\%\end{array}$ \\
\hline $\begin{array}{l}\text { Mining and } \\
\text { quarrying }\end{array}$ & 9 & $\begin{array}{l}13 \\
\%\end{array}$ & 23 & $\begin{array}{l}19 \\
\%\end{array}$ & 42 & $\begin{array}{l}18 \\
\%\end{array}$ & 41 & $\begin{array}{l}10 \\
\%\end{array}$ & 73 & $\begin{array}{l}10 \\
\%\end{array}$ & 83 & $\begin{array}{l}10 \\
\%\end{array}$ & 76 & $\begin{array}{l}10 \\
\%\end{array}$ & 76 & $\begin{array}{l}10 \\
\%\end{array}$ \\
\hline
\end{tabular}




\begin{tabular}{|c|c|c|c|c|c|c|c|c|c|c|c|c|c|c|c|c|}
\hline $\begin{array}{l}\text { Extraction of } \\
\text { crude } \\
\text { petroleum and } \\
\text { natural gas; }\end{array}$ & 1 & $\begin{array}{l}1 \\
\%\end{array}$ & 7 & $\begin{array}{l}6 \\
\%\end{array}$ & 104 & $\begin{array}{l}46 \\
\%\end{array}$ & 270 & $\begin{array}{l}67 \\
\%\end{array}$ & 539 & $\begin{array}{l}77 \\
\%\end{array}$ & 728 & $\begin{array}{l}86 \\
\%\end{array}$ & 666 & $\begin{array}{l}84 \\
\%\end{array}$ & 604 & $\begin{array}{l}82 \\
\%\end{array}$ \\
\hline $\begin{array}{l}\text { Wood, } \\
\text { publishing and } \\
\text { printing }\end{array}$ & 1 & $\begin{array}{l}1 \\
\%\end{array}$ & 8 & $\begin{array}{l}7 \\
\%\end{array}$ & 9 & $\begin{array}{l}4 \\
\%\end{array}$ & 19 & $\begin{array}{l}5 \\
\%\end{array}$ & 22 & $\begin{array}{l}10 \\
\%\end{array}$ & 10 & $\begin{array}{l}1 \\
\%\end{array}$ & 14 & $\begin{array}{l}2 \\
\%\end{array}$ & 16 & $\begin{array}{l}2 \\
\%\end{array}$ \\
\hline $\begin{array}{l}\text { Refined } \\
\text { petroleum \& } \\
\text { other } \\
\text { treatments }\end{array}$ & 0 & $\begin{array}{l}0 \\
\%\end{array}$ & 0 & $\begin{array}{l}0 \\
\%\end{array}$ & 0 & $\begin{array}{l}0 \\
\%\end{array}$ & 0 & $\begin{array}{l}0 \\
\%\end{array}$ & 0 & $\begin{array}{l}0 \\
\%\end{array}$ & 0 & $\begin{array}{l}0 \\
\%\end{array}$ & 0 & $\begin{array}{l}0 \\
\%\end{array}$ & 0 & $\begin{array}{l}0 \\
\%\end{array}$ \\
\hline $\begin{array}{l}\text { Chemical } \\
\text { products }\end{array}$ & 1 & $\begin{array}{l}1 \\
\%\end{array}$ & 9 & $\begin{array}{l}7 \\
\%\end{array}$ & 11 & $\begin{array}{l}5 \\
\%\end{array}$ & 13 & $\begin{array}{l}3 \\
\%\end{array}$ & 13 & $\begin{array}{l}2 \\
\%\end{array}$ & 2 & $\begin{array}{l}0 \\
\%\end{array}$ & 9 & $\begin{array}{l}1 \\
\%\end{array}$ & 8 & $\begin{array}{l}1 \\
\%\end{array}$ \\
\hline $\begin{array}{l}\text { Rubber and } \\
\text { plastic } \\
\text { products }\end{array}$ & 33 & $\begin{array}{l}46 \\
\%\end{array}$ & 14 & $\begin{array}{l}11 \\
\%\end{array}$ & 9 & $\begin{array}{l}4 \\
\%\end{array}$ & 9 & $\begin{array}{l}2 \\
\%\end{array}$ & 4 & $\begin{array}{l}1 \\
\%\end{array}$ & 4 & $\begin{array}{l}0 \\
\%\end{array}$ & 4 & $\begin{array}{l}1 \\
\%\end{array}$ & 6 & $\begin{array}{l}1 \\
\%\end{array}$ \\
\hline $\begin{array}{l}\text { Metal } \\
\text { products }\end{array}$ & 26 & $\begin{array}{l}37 \\
\%\end{array}$ & 62 & $\begin{array}{l}50 \\
\%\end{array}$ & 53 & $\begin{array}{l}23 \\
\%\end{array}$ & 51 & $\begin{array}{l}13 \\
\%\end{array}$ & 46 & $\begin{array}{l}7 \\
\%\end{array}$ & 17 & $\begin{array}{l}2 \\
\%\end{array}$ & 21 & $\begin{array}{l}3 \\
\%\end{array}$ & 24 & $\begin{array}{l}3 \\
\%\end{array}$ \\
\hline $\begin{array}{lr}\text { Total } & \text { FDI } \\
\text { stock } & \text { in } \\
\text { pollution } & \\
\text { intensive } & \\
\text { industries } & \end{array}$ & 71 & $\begin{array}{l}4 \\
\%\end{array}$ & 123 & $\begin{array}{l}6 \\
\%\end{array}$ & 228 & $\begin{array}{l}10 \\
\%\end{array}$ & 403 & $\begin{array}{l}17 \\
\%\end{array}$ & 697 & $\begin{array}{l}21 \\
\%\end{array}$ & 844 & $\begin{array}{l}22 \\
\%\end{array}$ & 790 & $\begin{array}{l}19 \\
\%\end{array}$ & 734 & $\begin{array}{l}16 \\
\%\end{array}$ \\
\hline $\begin{array}{ll}\text { TOTAL } & \text { FDI } \\
\text { STOCK } & \end{array}$ & $\begin{array}{l}1,8 \\
30\end{array}$ & & $\begin{array}{l}2,0 \\
61\end{array}$ & & $\begin{array}{l}2,2 \\
61\end{array}$ & & $\begin{array}{l}2,4 \\
36\end{array}$ & & $\begin{array}{l}3,4 \\
00\end{array}$ & & $\begin{array}{l}3,8 \\
93\end{array}$ & & $\begin{array}{l}4,1 \\
13\end{array}$ & & $\begin{array}{l}4,5 \\
53\end{array}$ & \\
\hline
\end{tabular}

Source: Bank of Albania IIP statistics and author's calculations, breakdown by activities according to NACE rev.1

Table 4.FDI stock in pollution-intensive services in Albania, 2007-2014, in million of euro and in $\%$ over total FDI stock

\begin{tabular}{|l|l|l|l|l|l|l|l|l|}
\hline FDI stock in million of euro & $\mathbf{2 0 0 7}$ & $\mathbf{2 0 0 8}$ & $\mathbf{2 0 0 9}$ & $\mathbf{2 0 1 0}$ & $\mathbf{2 0 1 1}$ & $\mathbf{2 0 1 2}$ & $\mathbf{2 0 1 3}$ & $\mathbf{2 0 1 4}$ \\
\hline Total FDI stock & 1,830 & 2,061 & 2,261 & 2,436 & 3,400 & 3,893 & 4,113 & 4,553 \\
\hline Total FDI stock in service & 1,443 & 1,358 & 1,415 & 1,583 & 1,572 & 1,959 & 2,680 & 2,768 \\
\hline in \% over total FDl stock & $79 \%$ & $66 \%$ & $63 \%$ & $65 \%$ & $46 \%$ & $50 \%$ & $65 \%$ & $61 \%$ \\
\hline $\begin{array}{l}\text { FDI stock in pollution intensive } \\
\text { services activities }\end{array}$ & 130 & 127 & 120 & 116 & 109 & 101 & 109 & 100 \\
\hline in \% over total FDI stock & $7 \%$ & $6 \%$ & $5 \%$ & $5 \%$ & $3 \%$ & $3 \%$ & $3 \%$ & $2 \%$ \\
\hline
\end{tabular}

Source: Bank of Albania, IIP statistics and author's calculations. 
Table 5.Total FDI stocks in pollution activities both, industry and service sectors

\begin{tabular}{|c|c|c|c|c|c|c|c|c|c|}
\hline & FDI stock in million of euro & 2007 & 2008 & 2009 & 2010 & 2011 & 2012 & 2013 & 2014 \\
\hline 1 & Total FDI stock & 1,830 & 2,061 & $\begin{array}{l}2,26 \\
1\end{array}$ & $\begin{array}{l}2,43 \\
6\end{array}$ & $\begin{array}{l}3,40 \\
0\end{array}$ & $\begin{array}{l}3,89 \\
3\end{array}$ & $\begin{array}{l}4,11 \\
3\end{array}$ & $\begin{array}{l}4,55 \\
3\end{array}$ \\
\hline 2 & Total FDI stock in service & 1,443 & 1,358 & $\begin{array}{l}1,41 \\
5\end{array}$ & $\begin{array}{l}1,58 \\
3\end{array}$ & $\begin{array}{l}1,57 \\
2\end{array}$ & $\begin{array}{l}1,95 \\
9\end{array}$ & $\begin{array}{l}2,68 \\
0\end{array}$ & $\begin{array}{l}2,76 \\
8\end{array}$ \\
\hline 3 & $\begin{array}{l}\text { FDI stock in pollution intensive services } \\
\text { activities }\end{array}$ & 130 & 127 & 120 & 116 & 109 & 101 & 109 & 100 \\
\hline 4 & Total FDI stock in industries & 387 & 703 & 846 & 853 & $\begin{array}{l}1,82 \\
8\end{array}$ & $\begin{array}{l}1,93 \\
4\end{array}$ & $\begin{array}{l}1,43 \\
3\end{array}$ & $\begin{array}{l}1,78 \\
5\end{array}$ \\
\hline 5 & $\begin{array}{l}\text { Total FDI stock in pollution intensive } \\
\text { industries }\end{array}$ & 71 & 123 & 228 & 403 & 697 & 844 & 790 & 734 \\
\hline 6 & Total stock FDI in pollution activities $(3+5)$ & 201 & 250 & 348 & 519 & 806 & 945 & 899 & 834 \\
\hline 7 & $\begin{array}{l}\text { Total stock FDI in pollution } \\
\text { activities,(industry and services) over total } \\
\text { FDI stocks }\end{array}$ & $11 \%$ & $12 \%$ & $15 \%$ & $21 \%$ & $24 \%$ & $24 \%$ & $22 \%$ & $18 \%$ \\
\hline
\end{tabular}

Source: Bank of Albania, IIP statistics and author's calculations.

Table 6.FDI stock in pollution-intensive industries in EU27 and in Albania

\begin{tabular}{|l|l|l|l|l|l|}
\hline $\begin{array}{l}\text { FDI stock in pollution intense activities over } \\
\text { total FDI stock, }\end{array}$ & $\begin{array}{l}\text { FDI originating } \\
\text { from EU27 } \\
(2006)\end{array}$ & $\begin{array}{l}\text { FDI originating } \\
\text { from non-EU27 } \\
(2006)\end{array}$ & Total & $\begin{array}{l}\text { Albania } \\
2007\end{array}$ & $\begin{array}{l}\text { Albania } \\
2014\end{array}$ \\
\cline { 2 - 6 } & $\%$ & $\%$ & $\%$ & $\%$ & $\%$ \\
\hline Mining and Quarrying & 2.9 & 2.5 & 2.8 & $0.5 \%$ & $1.7 \%$ \\
\hline $\begin{array}{l}\text { Extraction of crude petroleum and natural } \\
\text { gas; }\end{array}$ & 0 & 0 & 0 & $0.1 \%$ & $13.3 \%$ \\
\hline Wood, publishing and printing & 0.8 & 1.6 & 1 & $0.1 \%$ & $0.4 \%$ \\
\hline Refined petroleum \& other treatments & 0.7 & 0.8 & 0.7 & $0.0 \%$ & $0.0 \%$ \\
\hline Chemical products & 2.9 & 3.9 & 3.2 & $0.1 \%$ & $0.2 \%$ \\
\hline Rubber and plastic products & 0.7 & 0.4 & 0.6 & $1.8 \%$ & $0.1 \%$ \\
\hline Metal products & 1 & 0.8 & 1 & $1.4 \%$ & $0.5 \%$ \\
\hline Total FDI stock in pollution intensive & & & & & \\
\hline TOTAL FDI STOCK & $100 \%$ & $100 \%$ & $100 \%$ & $100 \%$ & $100 \%$ \\
\hline
\end{tabular}

Source: Report London Economics, 4 Nov. 2009, p. 56, Bank of Albania and author's calculations.

Table 7.FDI stock in pollution-intensive industries and services in EU27, (2011)

\begin{tabular}{|l|l|l|}
\hline FDI stock in billion of euro, 2011 & Value & in \% \\
\hline Mining and quarrying & 27.7 & $0.7 \%$ \\
\hline Manufacturing & 374.0 & $9.9 \%$ \\
\hline Textiles and wood activities & 11.5 & $0.3 \%$ \\
\hline Petroleum, chemical, pharmaceutical products & 139.3 & $3.7 \%$ \\
\hline Metal and machinery products & 72.6 & $1.9 \%$ \\
\hline Vehicles and other transport equipment & 39.1 & $1.0 \%$ \\
\hline
\end{tabular}




\begin{tabular}{|l|l|l|} 
Services & $3,283.0$ & $87.1 \%$ \\
\hline Trade; repairs of motor vehicles and motorcycles & 159.7 & $4.2 \%$ \\
\hline Transportation and storage & 25.9 & $0.7 \%$ \\
\hline Accommodation and food service activities & 11.8 & $0.3 \%$ \\
\hline Total FDI stock & $3,768.1$ & $8 \%$ \\
\hline
\end{tabular}

Source: EUROSTAT (online data code: bop_fdi_pos_r2),2012

\section{References}

[1] Bank

https://www.bankofalbania.org/web/Serite_kohore_22_1.php?evn=agregate_detaje\&evb=agregate\&cregtab_id =709\&periudha_id=5

[2] EUROSTAT (online data code: bop_fdi_pos_r2),2012 http://ec.europa.eu/eurostat/web/balance-ofpayments/data/database

[3] EC Brussels "Progress report Albania", commission staff working document (2015)

[4] Gentry B. G. "Foreign Direct Investment and the Environment: Bon or Bane" [in:] Foreign Direct Investment and the Environment, OECD Proceedings, Paris (1999),

[5] Ministry of Environment, Albania, "Annual report on environment,2015"

[6] Ministry of Environment, Albania," Draft strategy on environment" (2015-2020)

[7] Nick Mabey ,Richard McNally, "From pollution havens to sustainable development" WWF-UK Report , FDI and environment (1999)

[8] OECD, EUROSTAT, "The environmental goods and services industries "manual for data collection and analyses"(1999)

[9] OECD "Benchmark Definition of Foreign Direct Investment",(2008)

[10] OECD, Summary of the conference and discussion, [in:] Foreign Direct Investment and the Environment, OECD Proceedings, Paris (1999),

[11] Report London Economics p.56,4 November, (2009)

[12] UNCTAD ,FDI report in Albania, (2011)

[13] Witkowska J. "Foreign Direct Investment and Sustainable Development in the New EU Member States: Environmental Aspects" (2012) 